\title{
Maize grain concentrations and above-ground shoot acquisition of micronutrients as affected by intercropping with turnip, faba bean, chickpea, and soybean
}

\author{
XIA Hai Yong ${ }^{1}$, ZHAO JianHua ${ }^{2}$, SUN JianHao ${ }^{2}$, XUE YanFang $^{1}$, EAGLING Tristan ${ }^{3}$, \\ BAO XingGuo ${ }^{2}$, ZHANG FuSuo ${ }^{1} \&$ LI Long ${ }^{1 *}$ \\ ${ }^{1}$ Key Laboratory of Plant-Soil Interactions, Ministry of Education; College of Resources and Environmental Sciences, Center for Resources, \\ Environment and Food Security, China Agricultural University, Beijing 100193, China; \\ ${ }^{2}$ Institute of Soils, Fertilizers and Water-Saving Agriculture, Gansu Academy of Agricultural Sciences, Lanzhou 730070, China; \\ ${ }^{3}$ Rothamsted Research, Harpenden, Hertfordshire AL5 2JQ, UK
}

Received January 15, 2013; accepted May 7, 2013; published online July 26, 2013

\begin{abstract}
Most research on micronutrients in maize has focused on maize grown as a monocrop. The aim of this study was to determine the effects of intercropping on the concentrations of micronutrients in maize grain and their acquisition via the shoot. We conducted field experiments to investigate the effects of intercropping with turnip (Brassica campestris L.), faba bean (Vicia faba L.), chickpea (Cicer arietinum L.), and soybean (Glycine max L.) on the iron (Fe), manganese (Mn), copper $(\mathrm{Cu})$ and zinc $(\mathrm{Zn})$ concentrations in the grain and their acquisition via the above-ground shoots of maize (Zea mays L.). Compared with monocropped maize grain, the grain of maize intercropped with legumes showed lower concentrations of $\mathrm{Fe}, \mathrm{Mn}, \mathrm{Cu}$, and $\mathrm{Zn}$ and lower values of their corresponding harvest indexes. The micronutrient concentrations and harvest indexes in grain of maize intercropped with turnip were the same as those in monocropped maize grain. Intercropping stimulated the above-ground maize shoot acquisition of $\mathrm{Fe}, \mathrm{Mn}, \mathrm{Cu}$ and $\mathrm{Zn}$, when averaged over different phosphorus (P) application rates. To our knowledge, this is the first report on the effects of intercropping on micronutrient concentrations in maize grain and on micronutrients acquisition via maize shoots (straw+grain). The maize grain $\mathrm{Fe}$ and $\mathrm{Cu}$ concentrations, but not $\mathrm{Mn}$ and $\mathrm{Zn}$ concentrations, were negatively correlated with maize grain yields. The concentrations of $\mathrm{Fe}, \mathrm{Mn}, \mathrm{Cu}$, and $\mathrm{Zn}$ in maize grain were positively correlated with their corresponding harvest indexes. The decreased $\mathrm{Fe}, \mathrm{Mn}, \mathrm{Cu}$, and $\mathrm{Zn}$ concentrations in grain of maize intercropped with legumes were attributed to reduced translocation of $\mathrm{Fe}, \mathrm{Mn}, \mathrm{Cu}$, and $\mathrm{Zn}$ from vegetative tissues to grains. This may also be related to the delayed senescence of maize plants intercropped with legumes. We conclude that turnip/maize intercropping is beneficial to obtain high maize grain yield without decreased concentrations of $\mathrm{Fe}, \mathrm{Mn}, \mathrm{Cu}$, and $\mathrm{Zn}$ in the grain. Further research is required to clarify the mechanisms underlying the changes in micronutrient concentrations in grain of intercropped maize.
\end{abstract}

intercropping, maize, micronutrient, harvest index, dilution

Citation: Xia H Y, Zhao J H, Sun J H, et al. Maize grain concentrations and above-ground shoot acquisition of micronutrients as affected by intercropping with turnip, faba bean, chickpea, and soybean. Sci China Life Sci, 2013, 56: 823-834, doi: 10.1007/s11427-013-4524-y

Intercropping, which is the cultivation of two or more crops on a single piece of land, has many advantages over mono-

*Corresponding author (email: lilong@ @au.edu.cn) cropping. It can increase yields, has fewer negative effects on the environment, and is more ecologically sustainable [1]. Maize-based intercropping, especially with legumes, is predominant among intercropping systems. This cultivation 
practice is widespread in India, Southeast Asia, Latin America, Africa, and China [2]. The most significant benefits of maize-based intercropping are increased yields of maize. This may result from direct or indirect growth promotion by legumes or other crops, or from interspecific temporal and spatial niche complementarities. For example, legumes can directly facilitate nitrogen $(\mathrm{N})$ or phosphorus (P) uptake by maize $[3,4]$. Beneficial microorganisms can also mobilize nutrients and indirectly facilitate their uptake by maize [3]. Maize can also capture more solar radiation and water and nutrient resources through interspecific differences in above-ground plant height, belowground rooting depth, or seasonality (cool/warm) [4].

As a strategy-II plant, maize can secrete low-molecularmass secondary amino acids (mugineic acids) known as 'phytosiderophores' from its roots. These substances chelate sparingly soluble iron (Fe) for absorption and use [5]. Consequently, intercropping of maize and legumes on neutral or alkaline soils could ease Fe uptake to correct Fe deficiencies and increase the concentration of Fe in legume seeds [6]. However, few studies have focused on the acquisition of micronutrients by above-ground plant parts, or on the concentrations of micronutrients in grain of intercropped maize. Very recently, there has been some research on maize intercropping for bioremediation of heavy metal-contaminated soils, since maize is a hyperaccumulator of such metals [7].

Maize is a staple crop in many parts of the world, and is often targeted for micronutrient 'biofortification'. The three micronutrients most often lacking from human diets and necessary for maize growth are Fe, zinc ( $\mathrm{Zn})$, and copper (Cu) [8]. Research on maize biofortification has included conventional breeding and genetic modification [9] or agronomy practices [10], but all of these strategies have focused on maize cultivated as a monoculture. $\mathrm{Fe}$ and $\mathrm{Zn}$ remain the most studied micronutrients in terms of biofortification, while only limited research has been conducted on $\mathrm{Cu}$. Manganese $(\mathrm{Mn})$ is one of the eight trace elements essential for higher plants, but only a few studies have focused on Mn biofortification of maize [8].

The three most important factors for a successful biofortification strategy are high concentrations of the micronutrient(s) in the edible part of the crop, high yield, and high profitability [11]. Water regimes (pre-anthesis drought vs. irrigation throughout the vegetation cycle) did not affect the mineral composition of tropical maize grain. Application of $\mathrm{N}$ fertilizer increased the concentration of $\mathrm{Mn}$ in the grain, but the higher grain yield resulting from $\mathrm{N}$ fertilization resulted in a grain Zn 'dilution' effect [10]. Increasing N supply significantly improved the yield but had little effect on the grain $\mathrm{Zn}$ concentration in maize [12]. In addition, modern maize varieties with higher yields tend to contain lower concentrations of micronutrients in the grain, compared with those in grain of the lower-yield conventional varieties [10].

It is, therefore, important to know whether intercropping could be an effective agronomy practice to enhance or maintain concentrations of $\mathrm{Fe}, \mathrm{Mn}, \mathrm{Cu}$, and $\mathrm{Zn}$ in the maize grain, alongside the higher yields of intercropped maize, or whether there will be a 'dilution' effect as reported in studies on monocultured maize [10]. In addition, continuous $\mathrm{P}$ application over recent decades has led to a cumulative surplus of $\mathrm{P}$ in croplands. For example, the average Olsen-P has increased from 7.4 to $24.7 \mathrm{mg} \mathrm{kg}^{-1}$ during the last 30 years in China [13]. This situation threatens both the quality of the environment and food security because of overfertilization and limited reserves of phosphate rock [14]. Complex interactions of $\mathrm{P}$ with $\mathrm{Fe}, \mathrm{Mn}, \mathrm{Cu}$, and especially $\mathrm{Zn}$ have been studied since the 1960s, using various crops cultivated under different systems [15]. P application can negatively affect grain $\mathrm{Zn}$ concentration in cereal crops [16].

The objective of this research was to analyze the effects of intercropping on the micronutrient concentrations in maize tissues. We intercropped maize with faba bean, chickpea, soybean, and turnip and analyzed the concentrations of $\mathrm{Fe}, \mathrm{Mn}, \mathrm{Cu}$, and $\mathrm{Zn}$ in above-ground maize grain and straw). Also, to determine the effects of $\mathrm{P}$ on these interactions, we applied $\mathrm{P}$ at different rates to the various monocropping and intercropping systems. The four maizebased intercropping systems tested in this study are widespread and produce high crop yields in irrigated areas of temperate zones in northwestern China. This intercropping-rich part of China generally has only one relatively short cropping season each year because of temperature limitation.

\section{Materials and methods}

\subsection{Field location}

The field experiment was conducted in 2010 at Baiyun Experimental Station, Institute of Soils, Fertilizers and Water-Saving Agriculture, Gansu Academy of Agricultural Sciences, Gansu Province, China. Baiyun Experimental Station $\left(38^{\circ} 37^{\prime} \mathrm{N}, 102^{\circ} 40^{\prime} \mathrm{E}\right)$ is located $15 \mathrm{~km}$ north of Wuwei City, Gansu Province, at $1504 \mathrm{~m}$ above sea level. The annual mean temperature is $7.7^{\circ} \mathrm{C}$. The accumulated temperatures above $0^{\circ} \mathrm{C}$ and $10^{\circ} \mathrm{C}$ are $3646^{\circ} \mathrm{C}$ and $3149^{\circ} \mathrm{C}$, respectively. The frost-free period is $170-180 \mathrm{~d}$. Total solar radiation is $5988 \mathrm{MJ} \mathrm{m}^{-2} \mathrm{a}^{-1}$, annual precipitation is $150 \mathrm{~mm}$, and potential evaporation is $2021 \mathrm{~mm}$. The area is classified as having a typical arid climate and the soil at the site is classified as Aridisol (serozem).

\subsection{Experimental design}

We used a split-plot design with three replicates. The main plot treatments comprised three $\mathrm{P}$ application rates $(0,40$, or $80 \mathrm{~kg} \mathrm{P} \mathrm{hm}^{-2}$, applied as triple superphosphate) and the split-plot treatments consisted of nine cropping systems: 
maize (Zea mays L.) intercropping with turnip (Brassica campestris L.), faba bean (Vicia faba L.), chickpea (Cicer arietinum L.), or soybean (Glycine max L.), and corresponding monocultures of each crop.

Plants in all intercropping and monocropping plots were grown in an east-west row orientation. The area of the individual plots was $4.0 \mathrm{~m} \times 5.5 \mathrm{~m}$ for monocropped maize, turnip, faba bean, chickpea, and soybean, and $5.6 \mathrm{~m} \times 5.5 \mathrm{~m}$ for the intercropping systems (Figure 1). Each intercropped plot consisted of four strips, each 1.4-m wide. Two rows of maize alternated with three rows of legumes or turnip were planted in each strip; the inter-row distance was $40 \mathrm{~cm}$ for monocropped and intercropped maize and $20 \mathrm{~cm}$ for monocropped and intercropped legumes or turnip. There was a $30-\mathrm{cm}$ gap between maize rows and associated crop rows in the intercropping systems. Theoretically, the row design of the intercropping system resulted in two maize rows occupying $80 \mathrm{~cm}$ of the $140-\mathrm{cm}$ wide strip, and the three rows of the companion crop occupying $60 \mathrm{~cm}$. The inter-plant distance was $20 \mathrm{~cm}$ for maize and legume species. Turnip was planted by broadcast sowing in each row. The spacing was specifically designed to represent typical intercropping practices in the region. Maize rows occupied 80/140=57\% of the intercropped area and the companion rows occupied $60 / 140=43 \%$. To compare intercropped with monocropped plants, the density of maize or other crops in the intercropped plots was designed to be equal to that in the monoculture, based on the per unit of sown row area for maize or the companion crop. The experiment had a replacement design where the sum of relative sowing densities of the two species (sowing density in intercrop/sowing density in monocrop) was equal to one.

Nitrogen fertilizer was applied at an identical rate (112.5 $\mathrm{kg} \mathrm{hm}^{-2}$ as urea) to all legume species and turnip. This amount was $50 \%$ of that applied to maize. No potassium (K) or organic manure was applied to any crop. All the P fertilizer and $112.5 \mathrm{~kg} \mathrm{hm}^{-2}$ of the $\mathrm{N}$ fertilizer were evenly broadcasted and incorporated into the upper $20 \mathrm{~cm}$ of the soil prior to sowing. The other half of the $\mathrm{N}$ fertilizer for maize was divided into two portions and applied by top-dressing along with irrigation at the maize stem elongation stage and the pre-tasseling stage. All plots were irrigated adequately and all plants were weeded manually during the growing season. No fungicides were applied to either crop. At the peak flowering stage, omethoate (2-dimethoxyphosphinoylthio-N-methylacetamide; Dazhou Xinglong Chemical Co., Ltd., Dazhou, China) was used as a foliar spray to control aphids on faba bean.

The sowing dates were March 28 for faba bean, chickpea, and turnip and April 26 for maize and soybean. The harvest dates were June 28 for turnip when maize was at the elongation stage, July 28 for faba bean and chickpea when maize was at the tasseling stage, August 31 for soybean when maize was at the grain-filling stage, and October 5 for maize. The maize harvest date was almost 3 months after the harvest date for turnip, 2 months later than those for faba bean and chickpea, and 1 month later than that of soybean.

\subsection{Sample preparation and micronutrient analysis}

Grain and straw yields of intercropped and monocropped maize at maturity were measured by harvesting one intercropping strip from each intercropping plot and two adjacent rows of maize from each monoculture plot. After harvesting, maize straw and grain samples threshed by hand were dried at $65-70^{\circ} \mathrm{C}$ for $72 \mathrm{~h}$ after being washed rapidly with deionized water. Plant samples were ground with a stainless steel grinder (Model HY-04B, Beijing Xinhuanya, China) and subsamples were digested with $\mathrm{HNO}_{3}: \mathrm{H}_{2} \mathrm{O}_{2}$ $(6 \mathrm{~mL}: 2 \mathrm{~mL})$ in a microwave accelerated reaction system (CEM Corp., Matthews, NC, USA). The concentrations of $\mathrm{Fe}, \mathrm{Mn}, \mathrm{Cu}$, and $\mathrm{Zn}$ in the digested solutions were determined by inductively coupled plasma atomic emission

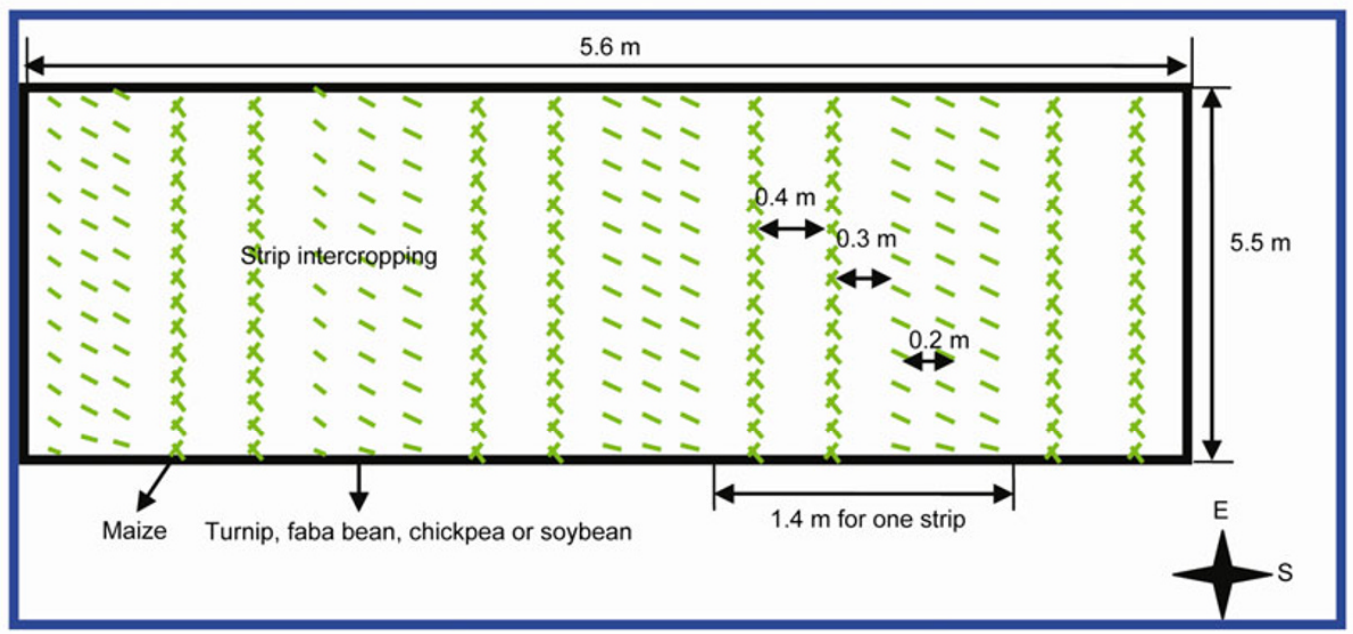

Figure 1 Diagram of strip intercropping field experiment. 
spectroscopy (ICP-AES; OPTIMA 3300 DV, Perkin-Elmer, Norwalk, CT, USA). Blanks and international certified reference materials (IPE556 for grain and IPE883 for straw, Wageningen University, The Netherlands) were used in each batch of digestions to ensure analytical quality.

\subsection{Statistical analysis}

Data from the split-plot design experiment were subjected to analysis of variance (ANOVA) using SAS for Windows ver. 8 and mean values $(n=3)$ were compared using the least significant difference (LSD) test at the 5\% level. Linear regressions and Pearson correlations were used to analyze the relationships between maize grain $\mathrm{Fe}, \mathrm{Mn}, \mathrm{Cu}, \mathrm{Zn}$ concentrations and grain yields or harvest indexes. All figures were drawn using SigmaPlot v. 10.0 (Systat Software Inc., San Jose, CA, USA).

\section{Results}

\subsection{Maize grain $\mathrm{Fe}, \mathrm{Mn}, \mathrm{Cu}$, and $\mathrm{Zn}$ concentrations}

The maize grain Mn concentration was higher in the $80 \mathrm{~kg}$ $\mathrm{P} \mathrm{hm}^{-2}$ treatment than in the $0 \mathrm{~kg} \mathrm{P} \mathrm{hm}^{-2}$ treatment, averaged over monoculture and intercropping systems (Figure 2 ). Compared with the Fe concentration in monocropped maize grain, $\mathrm{Fe}$ concentration in intercropped maize grain was not significantly lower, except for maize intercropped with faba bean or soybean in the $80 \mathrm{~kg} \mathrm{P} \mathrm{hm}^{-2}$ treatment (Figure 2). Under all $\mathrm{P}$ treatments, $\mathrm{Mn}$ and $\mathrm{Cu}$ concentrations were significantly lower in grain of maize intercropped with faba bean, chickpea, and soybean than in grain of monocropped maize, except for the Mn concentration in maize intercropped with chickpea in the $80 \mathrm{~kg} \mathrm{P} \mathrm{hm}^{-2}$ treatment (Figure 2). Compared with that in monocropped

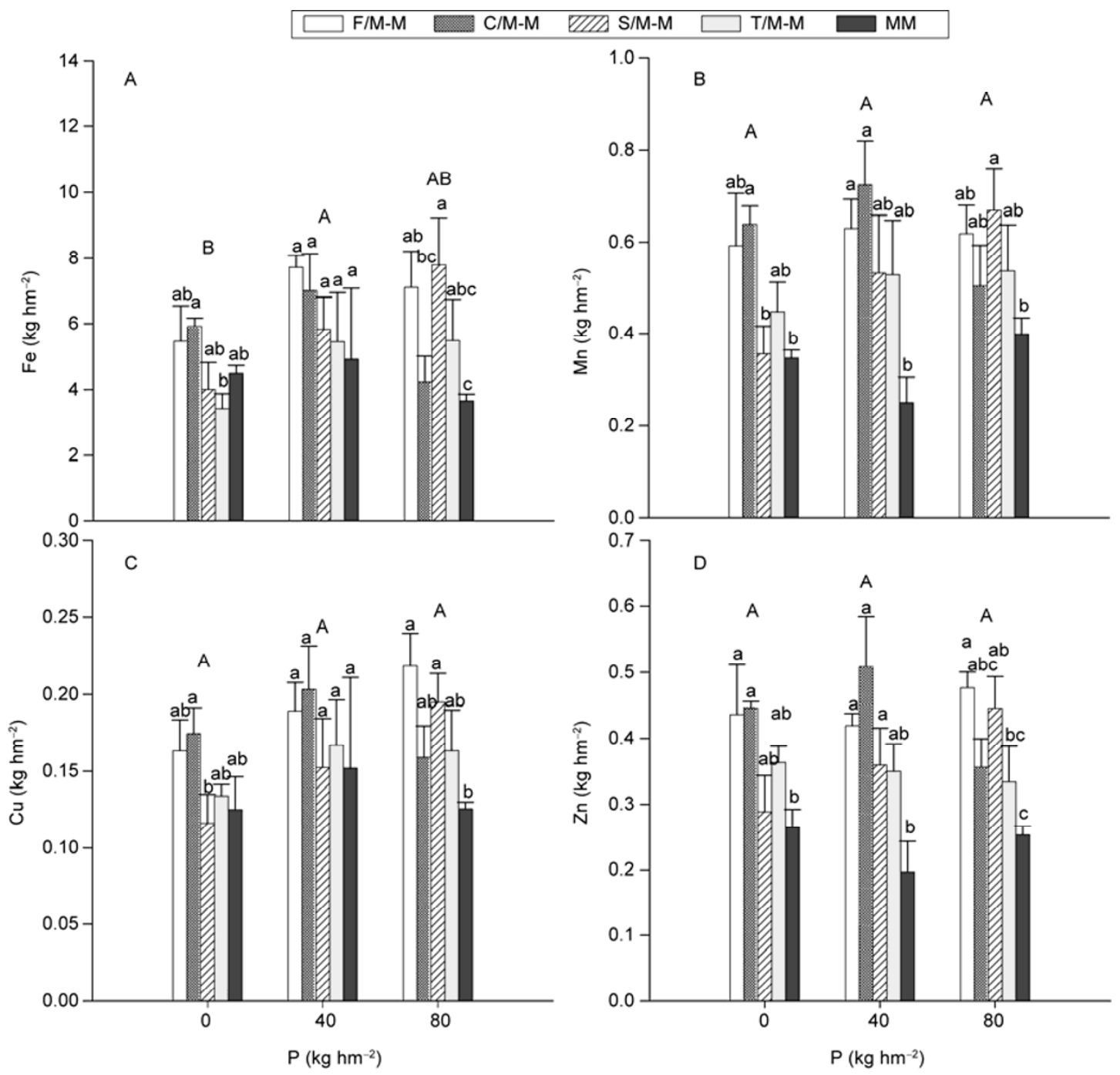

Figure 2 Concentrations of $\mathrm{Fe}, \mathrm{Mn}, \mathrm{Cu}$, and $\mathrm{Zn}$ in grain of monocropped and intercropped maize under different $\mathrm{P}$ application rates. Different capital letters indicate significant differences (at $\mathrm{LSD}_{0.05}$ ) among different $\mathrm{P}$ application rates. Different lowercase letters indicate significant differences (at LSD ${ }_{0.05}$ ) among different cropping systems under the same $\mathrm{P}$ application rate. F/M-M, C/M-M, S/M-M, T/M-M, and MM indicate maize intercropped with faba bean, chickpea, soybean, and turnip, and monocropped maize, respectively. 
maize grain, the $\mathrm{Zn}$ concentrations were lower in grain of maize intercropped with faba bean in all $\mathrm{P}$ treatments, with chickpea in the 0 and $40 \mathrm{~kg} \mathrm{P} \mathrm{hm}^{-2}$ treatments, and with soybean with no $\mathrm{P}$ application (Figure 2). Therefore, $\mathrm{P}$ application alleviated the decrease in $\mathrm{Zn}$ concentration of maize intercropped with chickpea and soybean, compared with that in monocropped maize grain (Figure 2). Intercropping with turnip did not significantly affect the $\mathrm{Fe}, \mathrm{Mn}, \mathrm{Cu}$, and $\mathrm{Zn}$ concentrations in maize grain, compared with those in monocropped maize grain (Figure 2). Averaged over the three $\mathrm{P}$ application rates, intercropping with faba bean, chickpea, and soybean significantly decreased the concentrations of $\mathrm{Fe}, \mathrm{Mn}, \mathrm{Cu}$ and $\mathrm{Zn}$ in maize grain, while intercropping with turnip did not (Figure 2).

\subsection{Maize grain $\mathrm{Fe}, \mathrm{Mn}, \mathrm{Cu}$, and $\mathrm{Zn}$ acquisition}

There were no significant differences in maize grain $\mathrm{Fe}, \mathrm{Mn}$, $\mathrm{Cu}$, and $\mathrm{Zn}$ acquisition among the different $\mathrm{P}$ treatments, averaged over maize monocropping and intercropping systems (Figure 3). Irrespective of $\mathrm{P}$ application rates, the $\mathrm{Fe}$ contents in grain of maize intercropped with faba bean, chickpea, soybean, or turnip were less affected by intercropping than by monocropping (Figure 3). The contents of both $\mathrm{Mn}$ and $\mathrm{Zn}$ in maize grain were increased by interspecific interactions between maize and the three legumes in the $40 \mathrm{~kg} \mathrm{P} \mathrm{hm}^{-2}$ treatment (Figure 3). However, interspecific interactions did not significantly affect the maize grain $\mathrm{Mn}$ and $\mathrm{Zn}$ contents in the 0 and $80 \mathrm{~kg} \mathrm{P} \mathrm{hm}^{-2}$ treatments,
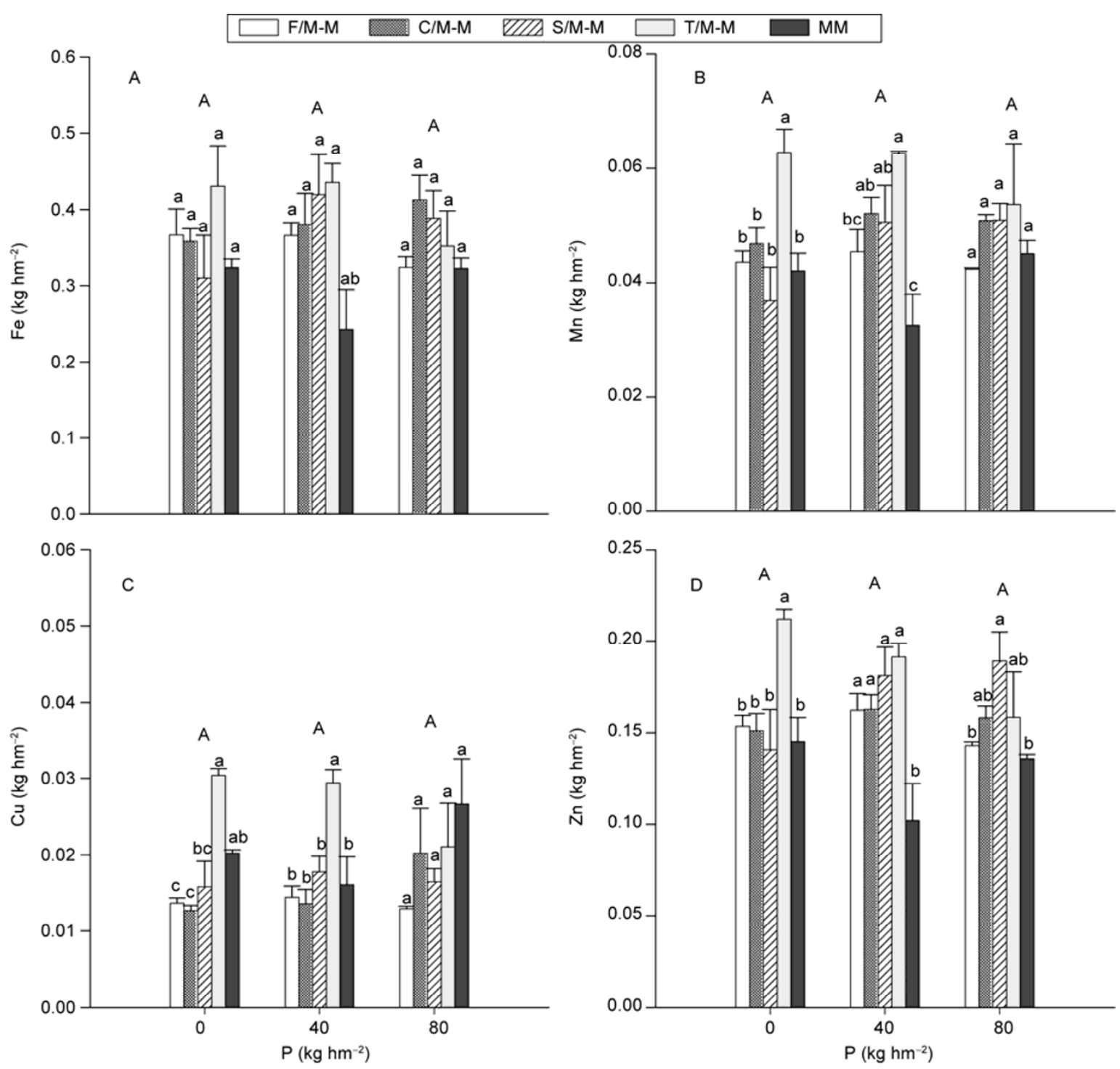

Figure 3 Grain $\mathrm{Fe}, \mathrm{Mn}, \mathrm{Cu}$, and $\mathrm{Zn}$ acquisition of monocropped and intercropped maize under different $\mathrm{P}$ application rates. Different capital letters indicate significant differences (at $\mathrm{LSD}_{0.05}$ ) among different $\mathrm{P}$ application rates. Different lowercase letters indicate significant differences (at LSD ${ }_{0.05}$ ) among different cropping systems under the same $\mathrm{P}$ application rate. F/M-M, C/M-M, S/M-M, T/M-M, and MM indicate maize intercropped with faba bean, chickpea, soybean, and turnip, and monocropped maize, respectively. 
except for maize intercropped with soybean, which showed a significant increase in $\mathrm{Zn}$ content of the grain in the $80 \mathrm{~kg}$ $\mathrm{P} \mathrm{hm}^{-2}$ treatment (Figure 3). Compared with that in grain of monocropped maize, the $\mathrm{Cu}$ contents in grain of maize intercropped with three legumes were decreased when no $\mathrm{P}$ fertilizer was applied, but were less affected by interspecific interactions with other crops in the 40 and $80 \mathrm{~kg} \mathrm{P} \mathrm{hm}^{-2}$ treatments (Figure 3). In contrast, the contents of $\mathrm{Mn}, \mathrm{Cu}$, and $\mathrm{Zn}$ in grain of maize intercropped with turnip were increased in the 0 and $40 \mathrm{~kg} \mathrm{P} \mathrm{hm}^{-2} \mathrm{P}$ treatments, but not in the $80 \mathrm{~kg} \mathrm{P} \mathrm{hm}^{-2}$ treatment (Figure 3 ).

\subsection{Maize above-ground shoot (grain+straw) Fe, Mn, $\mathrm{Cu}$, and $\mathrm{Zn}$ acquisition}

There were no significant differences in $\mathrm{Mn}, \mathrm{Cu}$, and $\mathrm{Zn}$ contents in above-ground shoots among the different $\mathrm{P}$ ap- plication rates (Figure 4). Only the Fe content was significantly increased in the $40 \mathrm{~kg} \mathrm{P} \mathrm{hm}{ }^{-2}$ treatment, compared with that in the $0 \mathrm{~kg} \mathrm{P} \mathrm{hm}{ }^{-2}$ treatment, averaged over monocropped and intercropped systems (Figure 4). Averaged over all $\mathrm{P}$ application rates, the $\mathrm{Fe}, \mathrm{Mn}, \mathrm{Cu}$, and $\mathrm{Zn}$ contents in above-ground shoots of monocropped maize were generally lower than those of maize intercropped with turnip, which were also generally lower than those of maize intercropped with legume crops (Figure 4). The $\mathrm{Fe}$ and $\mathrm{Cu}$ contents in above-ground maize shoots were significantly enhanced by interspecific interactions with faba bean or soybean in the $80 \mathrm{~kg} \mathrm{P} \mathrm{hm}^{-2}$ treatment, but their contents were not affected by interspecific interactions in the 0 and $40 \mathrm{~kg} \mathrm{P} \mathrm{hm}{ }^{-2}$ treatments (Figure 4). The Mn contents in above-ground shoots of maize intercropped with chickpea were significantly higher than those in above-ground shoots of monocropped maize in the $80 \mathrm{~kg} \mathrm{P} \mathrm{hm}^{-2}$ treatment (Fig-
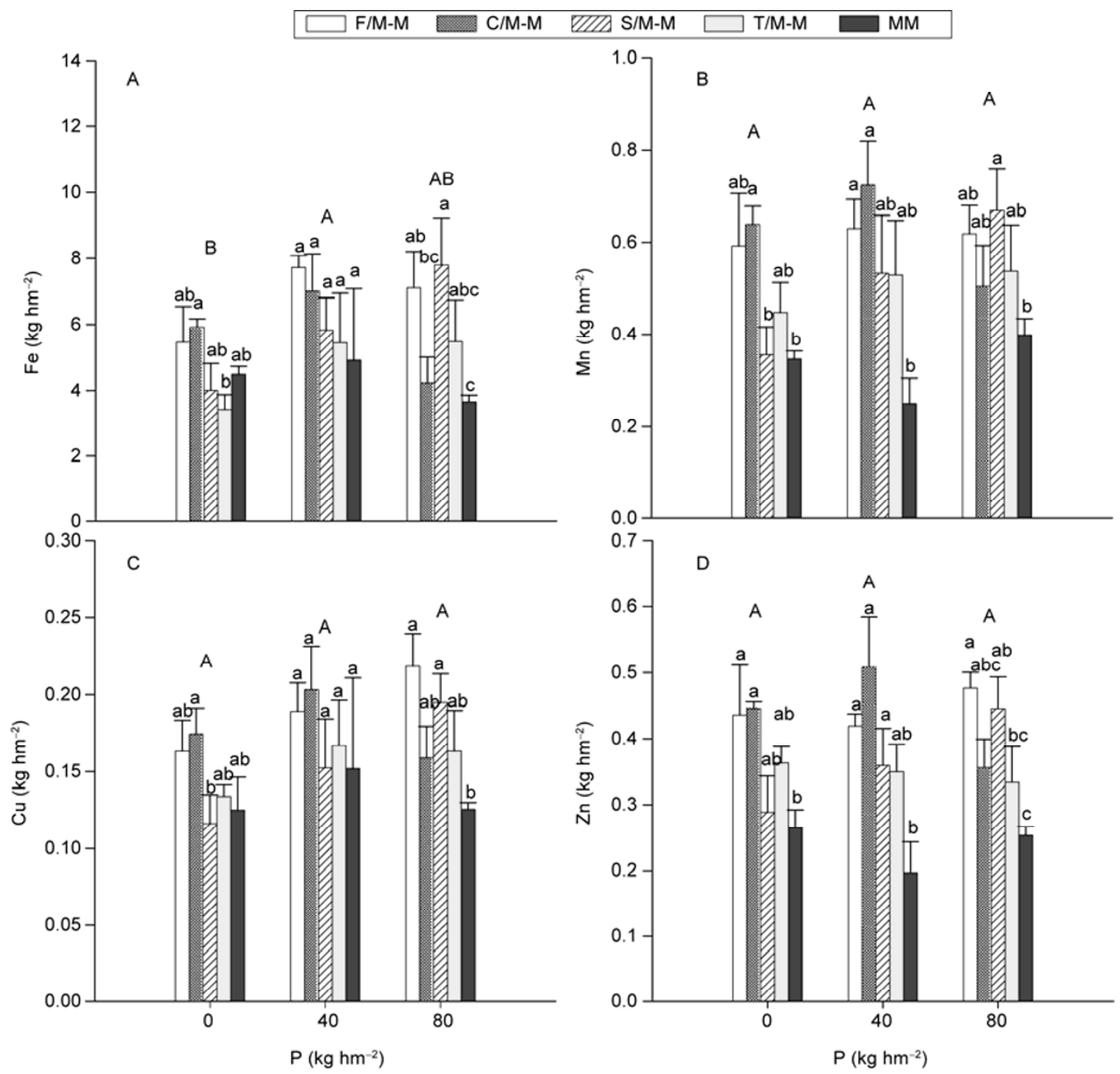

Figure $4 \mathrm{Fe}, \mathrm{Mn}, \mathrm{Cu}$ and $\mathrm{Zn}$ acquisition via above-ground maize shoots (straw+grain) under different $\mathrm{P}$ application rates. Different capital letters indicate significant differences (at $\mathrm{LSD}_{0.05}$ ) among different $\mathrm{P}$ application rates. Different lowercase letters indicate significant differences (at $\mathrm{LSD}_{0.05}$ ) among different cropping systems under the same $\mathrm{P}$ application rate. F/M-M, C/M-M, S/M-M, T/M-M and MM indicate maize intercropped with faba bean, chickpea, soybean, and turnip, and monocropped maize, respectively. 
ure 4). The Mn contents in above-ground shoots of maize intercropped with faba bean and soybean were greater than those in monocropped maize in the 40 and $80 \mathrm{~kg} \mathrm{P} \mathrm{hm}^{-2}$ treatments, respectively (Figure 4). The $\mathrm{Zn}$ contents in above-ground parts of maize intercropped with faba bean and chickpea were higher than those in above-ground shoots of monocropped maize in the 0 and $40 \mathrm{~kg} \mathrm{P} \mathrm{hm}^{-2}$ treatments (Figure 4). There was a significant difference in $\mathrm{Zn}$ content in above-ground shoots between monocropped maize and maize intercropped with faba bean in the $80 \mathrm{~kg} \mathrm{P} \mathrm{hm}^{-2}$ treatment (Figure 4). Compared with that in above-ground shoots of monocropped maize, the $\mathrm{Zn}$ contents in aboveground shoots of maize intercropped with soybean were enhanced in the 40 and $80 \mathrm{~kg} \mathrm{P} \mathrm{hm}^{-2}$ treatments (Figure 4).

\subsection{Maize grain harvest indexes}

We analyzed the maize grain harvest indexes (HIs) of Fe (FeHI), Mn (MnHI), Cu (CuHI) and $\mathrm{Zn}(\mathrm{ZnHI})$. There were no significant differences in maize grain FeHI, MnHI, CuHI and $\mathrm{ZnHI}$ among the different $\mathrm{P}$ treatments, averaged over monocropped and intercropped systems (Figure 5). Averaged over all of the $\mathrm{P}$ treatments, grain $\mathrm{MnHI}, \mathrm{CuHI}$, and $\mathrm{ZnHI}$ of monocropped maize and grain FeHI, MnHI, CuHI and $\mathrm{ZnHI}$ of maize intercropped with turnip were higher than those of maize intercropped with legume crops (Figure
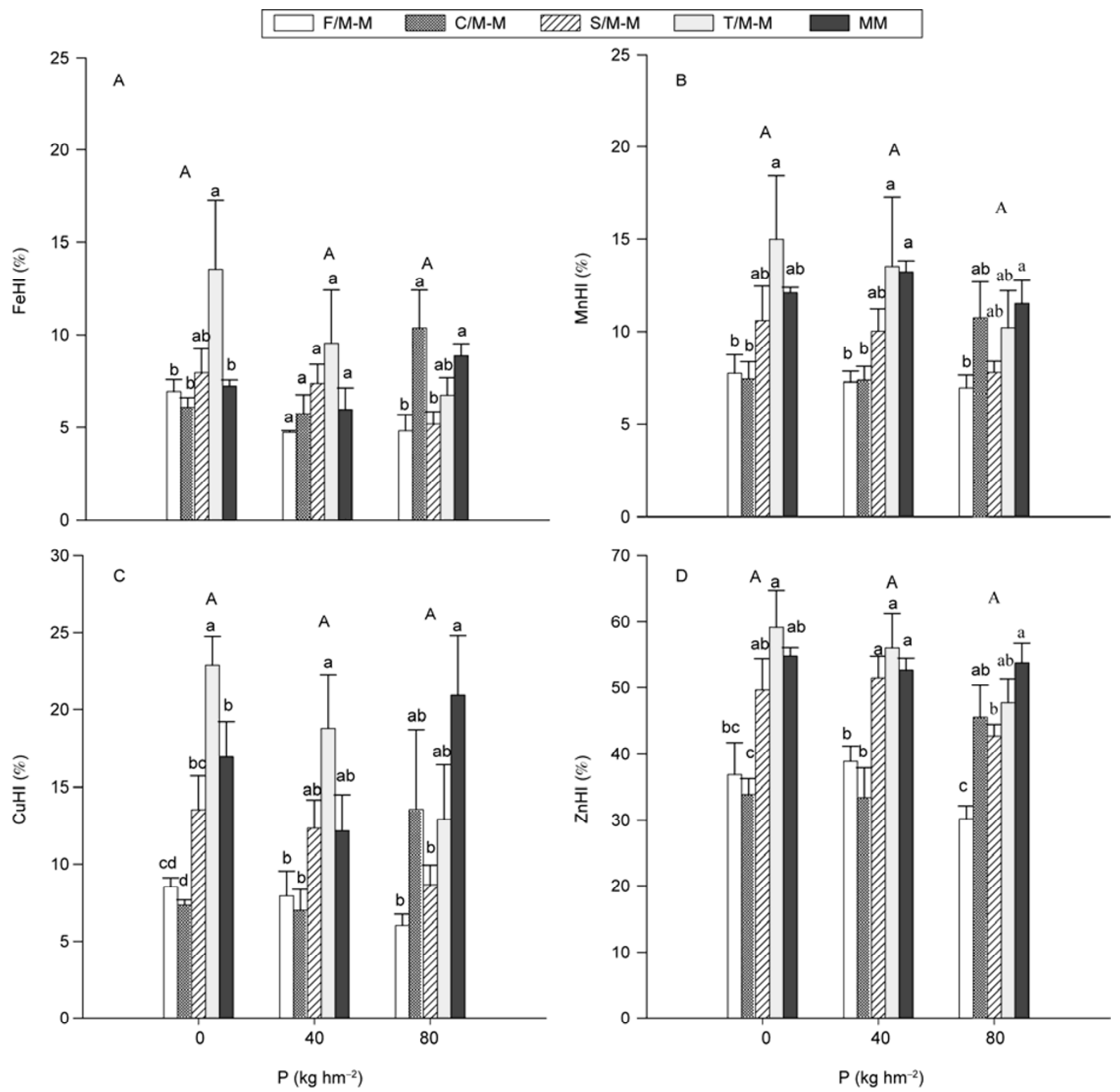

Figure 5 Harvest indexes (HIs) of grain $\mathrm{Fe}, \mathrm{Mn}, \mathrm{Cu}$, and $\mathrm{Zn}$ of monocropped and intercropped maize under different $\mathrm{P}$ application rates. Different capital letters indicate significant differences (at $\mathrm{LSD}_{0.05}$ ) among different $\mathrm{P}$ application rates. Different lowercase letters indicate significant differences (at $\mathrm{LSD}_{0.05}$ ) among different cropping systems under the same $\mathrm{P}$ application rate. F/M-M, C/M-M, S/M-M, T/M-M, and MM indicate maize intercropped with faba bean, chickpea, soybean, and turnip, and monocropped maize, respectively. 
5). The FeHIs of maize intercropped with faba bean and soybean were significantly lower than that of monocropped maize in the $80 \mathrm{~kg} \mathrm{P} \mathrm{hm}^{-2}$ treatment (Figure 5). The MnHIs of maize intercropped with faba bean in the 40 and $80 \mathrm{~kg} \mathrm{P}$ $\mathrm{hm}^{-2}$ treatments and chickpea in the $40 \mathrm{~kg} \mathrm{P} \mathrm{hm}^{-2}$ treatment were significantly lower than that of monocropped maize (Figure 5). The CuHIs of maize intercropped with faba bean in the 0 and $80 \mathrm{~kg} \mathrm{P} \mathrm{hm}^{-2}$ treatments, chickpea in the $0 \mathrm{~kg} \mathrm{P}$ $\mathrm{hm}^{-2}$ treatment, and soybean in the $80 \mathrm{~kg} \mathrm{P} \mathrm{hm}^{-2}$ treatment were significantly decreased by interspecific interactions, compared with the CuHI of monocropped maize (Figure 5). The ZnHIs of maize intercropped with faba bean in the 40 and $80 \mathrm{~kg} \mathrm{P} \mathrm{hm}^{-2}$ treatments, chickpea in the $0 \mathrm{~kg} \mathrm{P} \mathrm{hm}^{-2}$ treatment, and soybean in the $80 \mathrm{~kg} \mathrm{P} \mathrm{hm}^{-2}$ treatment were also significantly decreased by interspecific interactions, compared with the $\mathrm{ZnHI}$ of monocropped maize (Figure 5). There were no significant differences in FeHI, MnHI, CuHI, and $\mathrm{ZnHI}$ between monocropped maize and maize intercropped with turnip, except that the FeHI and CuHI of maize intercropped with turnip was significantly higher than those of monocropped maize in the $0 \mathrm{~kg} \mathrm{P} \mathrm{hm}^{-2}$ treatment (Figure 5).

\subsection{Relationships between maize grain $\mathrm{Fe}, \mathrm{Mn}, \mathrm{Cu}$, and $\mathrm{Zn}$ concentrations and grain yields}

The grain yields of intercropped maize were greater than that of monocropped maize, but the concentrations of $\mathrm{Fe}$, $\mathrm{Mn}, \mathrm{Cu}$, and $\mathrm{Zn}$ were lower in intercropped maize grain than in monocropped maize grain (Figures 2 and 6). Maize grain $\mathrm{Fe}$ and $\mathrm{Cu}$ concentrations showed significant negative linear correlations with grain yields, irrespective of $\mathrm{P}$ application rates and cropping systems (Figure 6).

2.6 Relationships between maize grain $\mathrm{Fe}, \mathrm{Mn}, \mathrm{Cu}$, and $\mathrm{Zn}$ concentrations and harvest indexes

There were significant positive linear correlations between maize grain $\mathrm{Fe}, \mathrm{Mn}, \mathrm{Cu}, \mathrm{Zn}$ concentrations and their respective HIs (Figure 7).

\section{Discussion}

\subsection{Effects of phosphorus application rate}

The results of this study show that the effects of $\mathrm{P}$ application rates on the concentrations of $\mathrm{Fe}, \mathrm{Mn}, \mathrm{Cu}$, and $\mathrm{Zn}$ in maize grain, on the acquisition of $\mathrm{Fe}, \mathrm{Mn}, \mathrm{Cu}$, and $\mathrm{Zn}$ via maize grain and total above-ground shoot, and on their corresponding harvest indexes, were generally not significant (Figures 2-5). The different $\mathrm{P}$ application rates did not affect maize grain yields significantly (data not shown). This may be because of a higher cumulative surplus of $\mathrm{P}$ in soils from previous over-fertilization by local farmers.

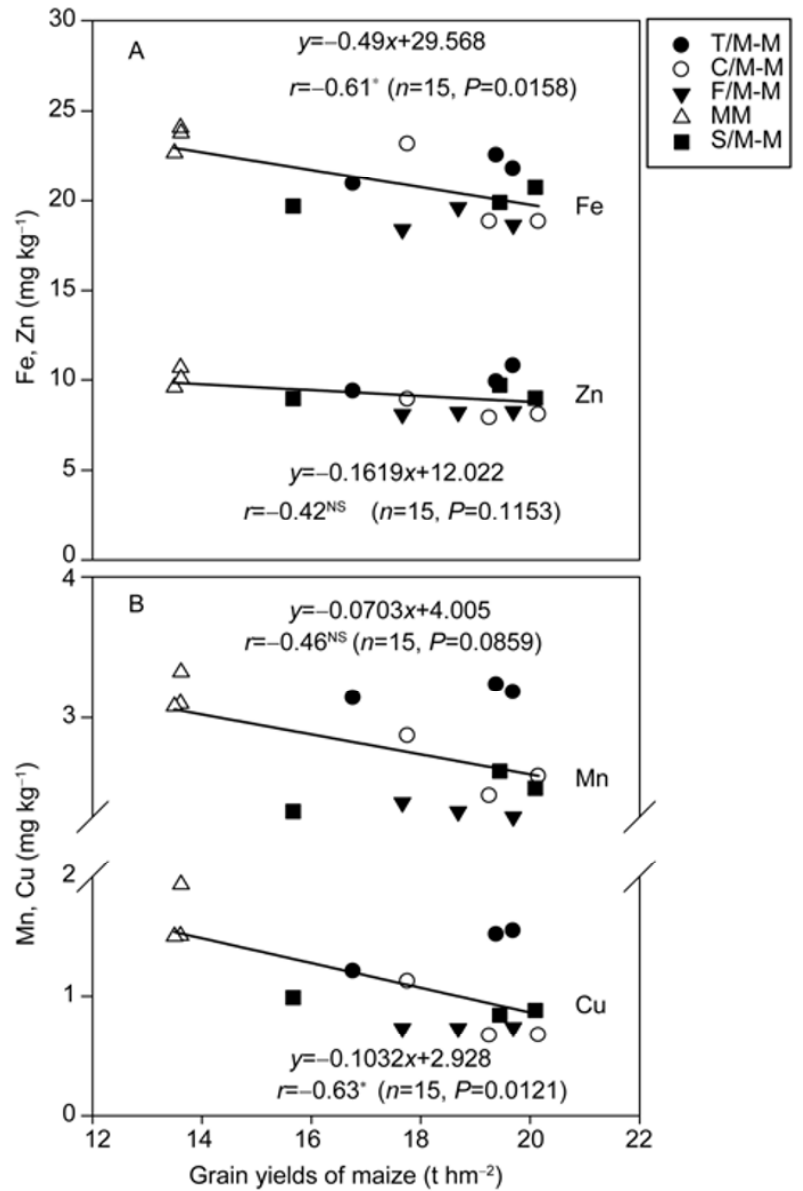

Figure 6 Relationships between maize grain $\mathrm{Fe}, \mathrm{Mn}, \mathrm{Cu}, \mathrm{Zn}$ concentrations and maize grain yields. NS indicates not statistically significant; *, significant at $P<0.05$.

\subsection{Grain micronutrient 'dilution' may not be caused by higher grain yields}

Previous studies showed that intercropping of maize, especially with legumes, led to higher grain yields of maize compared with that of monocropped maize [4]. To our knowledge, this is the first report that grain of maize intercropped with faba bean, chickpea, and soybean shows dramatically decreased $\mathrm{Fe}, \mathrm{Mn}, \mathrm{Cu}$, and $\mathrm{Zn}$ concentrations (Figure 2). One reason for this may be that the higher yields of maize led to a 'dilution' effect on micronutrients in the grain. In a previous study, $\mathrm{N}$ fertilization led to higher maize grain yield, which had a dilution effect on grain $\mathrm{Zn}$ concentration [10]. In another study, multiple regression analyses showed that both increasing yield and harvest index were significant factors explaining the downward trend in wheat grain mineral concentrations [17]. Similarly, yield stimulation caused by rising $\mathrm{CO}_{2}$ led to a decrease in $\mathrm{Zn}$ concentration in wheat grain [18].

In the present study, the maize grain harvest index was not affected by intercropping (data not shown). Pearson 

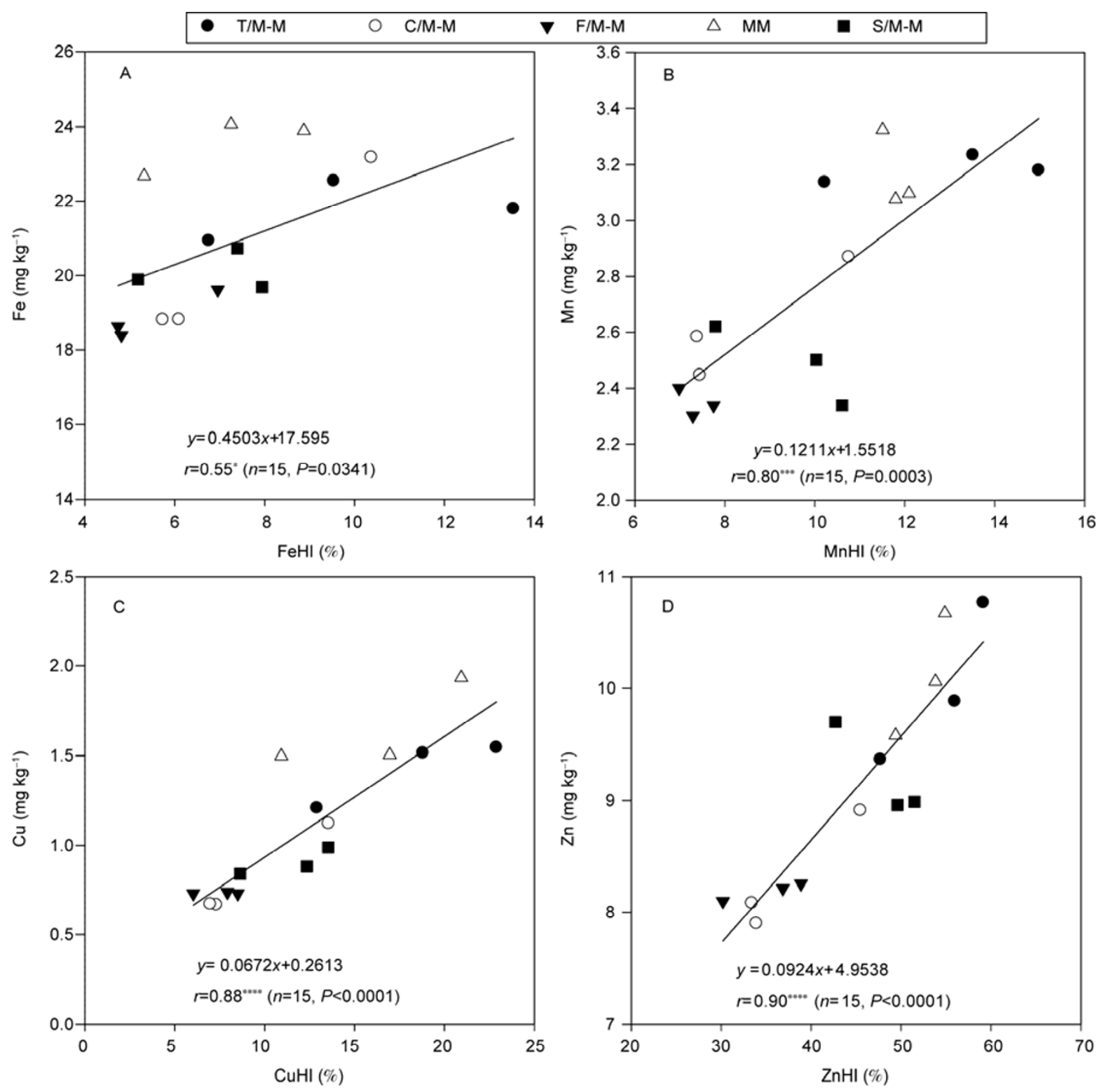

Figure 7 Relationships between maize grain $\mathrm{Fe}, \mathrm{Mn}, \mathrm{Cu}, \mathrm{Zn}$ concentrations and their corresponding HIs. NS indicates not statistically significant; *, significant at $P<0.05$; ***, significant at $P<0.001 ; * * * *$, significant at $P<0.0001$.

correlation analyses showed there were no significant correlations between harvest indexes of grain yields and grain $\mathrm{Fe}, \mathrm{Mn}, \mathrm{Cu}, \mathrm{Zn}$ concentrations (Table 1). Higher grain yields of maize were also not sufficient to explain the dilution of grain $\mathrm{Fe}, \mathrm{Mn}, \mathrm{Cu}$, and $\mathrm{Zn}$. There were significant negative linear correlations between maize grain yields and grain $\mathrm{Fe}$ or $\mathrm{Cu}$ concentrations, but the negative correlations between maize grain yields and $\mathrm{Mn}$ and $\mathrm{Zn}$ concentrations were not significant (Figure 5, Table 1). Therefore, the 'dilution' effect caused by higher grain yields did not appear to be responsible for the reduction in maize grain $\mathrm{Mn}$ and $\mathrm{Zn}$ concentrations. In a previous study, $\mathrm{N}$ application increased the maize grain $\mathrm{Mn}$ concentration [10]. Another study showed that increasing the $\mathrm{N}$ supply significantly improved yield, but it had little effect on maize grain $\mathrm{Zn}$ concentration [12].

Although the grain yield of maize intercropped with turnip was greater than that of monocropped maize, it did not lead to a grain $\mathrm{Fe}, \mathrm{Mn}, \mathrm{Cu}, \mathrm{Zn}$ 'dilution' effect; that is, the $\mathrm{Fe}, \mathrm{Mn}, \mathrm{Cu}$, and $\mathrm{Zn}$ concentrations in grain of maize intercropped with turnip were the same as those in monocropped maize grain (Figure 2). This phenomenon differed markedly from that observed in maize intercropped with legume crops. As shown in Figure 6, the data of maize intercropped with turnip deviated widely from data of maize intercropped with legumes; this resulted in insignificant negative linear correlations between maize grain yields and grain $\mathrm{Mn}$ or $\mathrm{Zn}$ concentrations. If the data from maize intercropped with 
Table 1 Pearson correlations between maize grain $\mathrm{Fe}, \mathrm{Mn}, \mathrm{Cu}$, and $\mathrm{Zn}$ concentrations and grain yields or harvest indexes (HIs) ${ }^{\text {a) }}$

\begin{tabular}{clcc}
\hline $\begin{array}{c}\text { Maize } \\
\text { grain micronutrients }\end{array}$ & Grain yields & $\begin{array}{c}\text { Grain yields } \\
\text { excluding T/M-M }\end{array}$ & $\begin{array}{c}\text { HIs of } \\
\text { grain yields }\end{array}$ \\
\hline $\mathrm{Fe}$ & $-0.610^{*}$ & $-0.750^{* *}$ & $0.195^{\mathrm{NS}}$ \\
$\mathrm{Mn}$ & $-0.458^{\mathrm{NS}}$ & $-0.751^{* *}$ & $0.233^{\mathrm{NS}}$ \\
$\mathrm{Cu}$ & $-0.629^{*}$ & $-0.883^{* * *}$ & $0.229^{\mathrm{NS}}$ \\
$\mathrm{Zn}$ & $-0.424^{\mathrm{NS}}$ & $-0.722^{*}$ & $0.802^{* * *}$ \\
$0.412^{\mathrm{NS}}$ & $0.881^{* * * *}$ \\
\hline
\end{tabular}

a) T/M-M, maize intercropped with turnip; NS, not statistically significant; *, significant at $P<0.05 ; * *$, significant at $P<0.01$; $* * *$, significant at $P<0.001$; ****, significant at $P<0.0001$.

turnip were excluded, the negative linear correlations became significant (Table 1).

\subsection{Lower concentrations of micronutrients in inter- cropped maize were due to lower micronutrient harvest indexes and delayed maize senescence}

There were similar trends in maize grain $\mathrm{Fe}, \mathrm{Mn}, \mathrm{Cu}$, and $\mathrm{Zn}$ concentrations (Figure 2) and their corresponding harvest indexes (Figure 5). This indicated that grain $\mathrm{Mn}, \mathrm{Cu}$, and $\mathrm{Zn}$ concentrations and their corresponding HIs of maize intercropped with faba bean, chickpea, and soybean were generally lower than those of monocropped maize and maize intercropped with turnip, irrespective of the P application rate. Compared with the correlations between grain $\mathrm{Fe}, \mathrm{Mn}, \mathrm{Cu}$, and $\mathrm{Zn}$ concentrations and grain yields, grain $\mathrm{Fe}, \mathrm{Mn}, \mathrm{Cu}$, and $\mathrm{Zn}$ concentrations were more significantly and positively correlated with their corresponding harvest indexes (Table 1).

There were no significant differences in HIs of grain yields between monocropped and intercropped maize. However, the $\mathrm{Mn}, \mathrm{Cu}$, and $\mathrm{Zn}$ HIs of maize intercropped with faba bean, chickpea, and soybean were lower than those of monocropped maize and maize intercropped with turnip (Figure 5). Thus, it is likely that the distribution or mobilization of $\mathrm{Mn}, \mathrm{Cu}$, and $\mathrm{Zn}$ from the vegetative tissue to the grain did not keep up with the distribution or translocation of photosynthates in maize grown with faba bean, chickpea, and soybean. Research has shown that translocation or remobilization of micronutrients from vegetative tissues to the grain may play an important role in determining the concentrations of micronutrients in maize grain. For example, under high $\mathrm{N}$ and $\mathrm{Zn}$ application rates, about $60 \%$ of $\mathrm{Zn}$ and $40 \%$ of Fe initially stored in vegetative parts were remobilized to wheat grain. A high $\mathrm{N}$ application rate contributed to uptake and remobilization of both $\mathrm{Zn}$ and $\mathrm{Fe}$ from wheat vegetative tissues under greenhouse conditions with sufficient irrigation and $\mathrm{Zn}$ supply [19]. Also, enhanced $\mathrm{N}$ supply increased grain $\mathrm{Zn}$ and Fe concentrations under field conditions [20]. There are several mechanisms that underlie the micronutrient 'dilution' effect. Because $\mathrm{N}$ and $\mathrm{Zn}$ are mainly located in the outer layers of maize kernels, a higher proportion of endosperm to total grain weight explains the yield 'dilution' effect of grain weight [21]. In maize, the number of grains also contributes to yield 'dilution' effects. This is likely because a larger number of grains depend on the development of a larger proportion of distal grains, which typically have lower levels of minerals such as Zn [22]. In a previous study, grain weight and grain number showed significant negative linear correlations with grain $\mathrm{Zn}$ concentration [18]. Our results suggest that the decreased concentrations of $\mathrm{Mn}, \mathrm{Cu}, \mathrm{Zn}$, and $\mathrm{Fe}$ in maize grain resulted from reduced translocation or remobilization of these micronutrients from straw to grain. This explanation is more consistent with our results than is the 'dilution' effect caused by higher grain yield.

Senescence induced $\mathrm{Fe}$ mobilization in source leaves of barley (Hordeum vulgare) [23]. The NAC gene product, which regulates senescence, was shown to increase grain protein, zinc, and iron concentrations in wheat, while a reduction in the transcript levels of multiple NAM homologs by RNA interference delayed senescence by more than three weeks and decreased concentrations of protein, $\mathrm{Zn}$, and $\mathrm{Fe}$ in wheat grain by more than $30 \%$ [24]. Similarly, in our research, maize grain $\mathrm{Fe}, \mathrm{Mn}, \mathrm{Cu}$, and $\mathrm{Zn}$ concentrations and their corresponding harvest indexes may be related to the initiation of senescence. At harvest, maize grown with faba bean, chickpea, and soybean had a larger portion of green leaves compared with that of monocropped and maize intercropped with turnip. The latter two maize crops reached senescence about one week earlier (Figure 8), and consequently showed higher grain $\mathrm{Fe}, \mathrm{Mn}, \mathrm{Cu}$ and $\mathrm{Zn}$ HIs than those of maize intercropped with legumes. This may explain the higher concentrations of $\mathrm{Fe}, \mathrm{Mn}, \mathrm{Cu}$, and $\mathrm{Zn}$ in monocropped maize and maize intercropped with turnip, compared with those in maize intercropped with legumes. Consistent with our results, other studies also suggested that differences in micronutrient concentrations/bioavailability can be due to the environmental conditions from the flowering to maturity stages, differences in the duration of the post-physiological maturity period during which the grain remains on the plant in the field, differences in genotypes, and/or differences in the harvest time [25,26]. Although appropriate $\mathrm{N}$ application may delay senescence [27], it can increase the maize grain Fe concentration [20]. The results of our research should be further verified under different conditions; for example, under different harvest times and different cropping seasons. There were higher contents of 


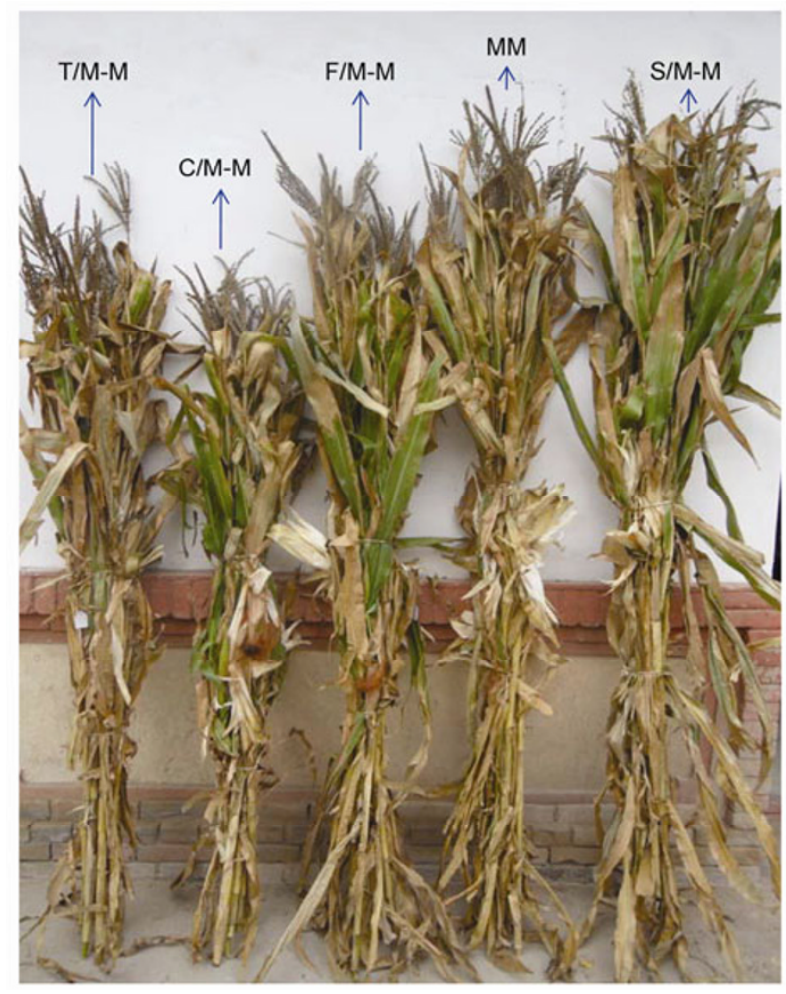

Figure 8 Harvested above-ground shoots of maize grown under field conditions. Compared with maize intercropped with turnip and monocropped maize, maize grown with faba bean, chickpea, and soybean matured later (visible as larger amounts of green leaves). MM, T/M-M, C/M-M, F/M-M, and S/M-M indicate monocropped maize and maize intercropped with turnip, chickpea, faba bean, and soybean, respectively.

$\mathrm{Mn}, \mathrm{Cu}, \mathrm{Zn}$ and $\mathrm{Fe}$ in the straw and lower translocation or remobilization ratios to grain in maize grown with legumes, compared with those in monocropped maize or maize intercropped with turnip. The mechanisms underlying these physiological differences in nutrient accumulation and translocation should be explored in future research.

\subsection{Enhanced micronutrient acquisition by inter- cropped maize and its possible mechanisms}

The concentrations of $\mathrm{Fe}, \mathrm{Mn}, \mathrm{Cu}$, and $\mathrm{Zn}$ in grain of maize intercropped with faba bean, chickpea, and soybean were lower than those in grain of monocropped maize (Figure 2). However, the corresponding $\mathrm{Fe}, \mathrm{Mn}$, and $\mathrm{Zn}$ uptake by grain of intercropped maize with the legume species were not decreased, and even increased to some extent, when averaged over all $\mathrm{P}$ application rates (Figure 3). Maize intercropped with legumes showed higher contents of $\mathrm{Fe}, \mathrm{Mn}$, $\mathrm{Cu}$, and $\mathrm{Zn}$ in above-ground shoots, compared with those in above-ground shoots of monocropped maize, when averaged over all $\mathrm{P}$ application rates (Figure 4). The Fe, $\mathrm{Mn}, \mathrm{Cu}$, and $\mathrm{Zn}$ contents in maize grain (Figure 3 ) and in the whole above-ground shoots of maize intercropped with turnip (Figure 4) were also higher than those in the respective tis- sues of monocropped maize, when averaged over all P application rates.

There are two main reasons that may explain the increased $\mathrm{Fe}, \mathrm{Mn}, \mathrm{Cu}$, and $\mathrm{Zn}$ accumulation ability of intercropped maize. One is that intercropping can enhance secretion of acid phosphatase and organic acids from maize roots, and this may facilitate its absorption of soil micronutrients [4]. The other reason is that the longer life span and the larger space occupied by the roots of intercropped maize compared with those of monocropped maize may help intercropped maize acquire adequate micronutrients [28]. The concentrations of heavy metals, especially $\mathrm{Cr}$, were lower in intercropped maize grain than in monocropped maize grain [7]. This was consistent with our results for $\mathrm{Fe}, \mathrm{Mn}, \mathrm{Cu}$, and $\mathrm{Zn}$ (Figure 2). For phytoremediation of heavy metalcontaminated soils, maize intercropping is a practical strategy to obtain a crop that is safe for consumption [7]. For Fe, $\mathrm{Mn}, \mathrm{Cu}$, and $\mathrm{Zn}$, intercropping of maize with faba bean, chickpea, and soybean may not be beneficial for 'biofortification' of maize grain. In future research, it would be useful to evaluate which parts of the maize grain contain decreased concentrations of $\mathrm{Fe}, \mathrm{Mn}, \mathrm{Cu}$, and $\mathrm{Zn}$, and whether the bioavailability and/or speciation of $\mathrm{Fe}, \mathrm{Mn}, \mathrm{Cu}$, and $\mathrm{Zn}$ in maize grain is affected by intercropping.

In the present study, different dates for sowing and harvesting were specified for the different crops, monocropped maize and maize intercropped with turnip, faba bean, chickpea, and soybean were sown on the same date and also harvested on the same date. Different types and varieties of companion crops with different sowing and harvest dates, may affect the micronutrient nutrition of maize. For example, compared with the grain of monocropped maize, the grain of maize intercropped with legumes showed lower Fe, $\mathrm{Mn}, \mathrm{Cu}$, and $\mathrm{Zn}$ concentrations and lower corresponding harvest indexes, while those of maize intercropped with turnip were the same as those of monocropped maize.

It was reported that growing maize alongside legumes on neutral and alkaline soils could facilitate Fe uptake to correct $\mathrm{Fe}$ deficiencies and increase the concentration of $\mathrm{Fe}$ in legume seeds [6]. The aim of this study was to investigate the effects of intercropping with different companion crops on maize grain $\mathrm{Fe}, \mathrm{Mn}, \mathrm{Cu}$ and $\mathrm{Zn}$ concentrations and corresponding above-ground shoot acquisition; therefore, we did not analyze the micronutrient concentrations in turnip, faba bean, chickpea, and soybean plants. In future research, it would be useful to analyze micronutrients in the companion crops as well as in the main crop. This would give a better understanding of the effects of intercropping on micronutrient nutrition of the whole cropping system.

This work was supported by the National Natural Science Foundation of China (30890133), the National Basic Research Program of China (2011CB100405), and China Agricultural University Specialized Research 
Fund to Support Ph.D. Candidates Innovative and Independent Scientific Subject (KYCX2010075).

1 Vandermeer J. The Ecology of Intercropping. New York: Cambridge University Press, 1989

2 Knoerzer H, Graeff-Hoenninger S, Guo B, et al. The rediscovery of intercropping in China: a traditional cropping system for future Chinese agriculture - a review. In: Lichtfouse E, ed. Climate Change, Intercropping, Pest Control and Beneficial Microorganisms. New York: Springer, 2009. 13-44

3 Hauggaard-Nielsen H, Jensen E S. Facilitative root interactions in intercrops. Plant Soil, 2005, 274: 237-250

4 Li L, Li S M, Sun J H, et al. Diversity enhances agricultural productivity via rhizosphere phosphorus facilitation on phosphorus-deficient soils. Proc Natl Acad Sci USA, 2007, 104: 11192-11196

5 Römheld V, Marschner H. Evidence for a specific uptake system for iron phytosiderophores in roots of grasses. Plant Physiol, 1986, 80: 175-180

6 Zuo Y M, Zhang F S, Li X L, et al. Studies on the improvement in iron nutrition of peanut by intercropping with maize on a calcareous soil. Plant Soil, 2000, 220: 13-25

7 An L Y, Pan Y H, Wang Z B, et al. Heavy metal absorption status of five plant species in monoculture and intercropping. Plant Soil, 2011, 345: 237-245

8 White P J, Broadley M R. Biofortifying crops with essential mineral elements. Trends Plant Sci, 2005, 10: 586-593

9 Pixley K V, Palacios-Rojas N, Glahn R P. The usefulness of iron bioavailability as a target trait for breeding maize (Zea mays L.) with enhanced nutritional value. Field Crop Res, 2011, 123: 153-160

10 Feil B, Moser S B, Jampatong S, et al. Mineral composition of the grains of tropical maize varieties as affected by pre-anthesis drought and rate of nitrogen fertilization. Crop Sci, 2005, 45: 516-523

11 Bouis H E, Hotz C, McClafferty B, et al. Biofortification: a new tool to reduce micronutrient malnutrition. Food Nutr Bull, 2011, 32: S31-S40

12 Bruns H A, Ebelhar M W. Nutrient uptake of maize affected by nitrogen and potassium fertility in a humid subtropical environment. Commun Soil Sci Plant Anal, 2006, 37: 275-293

13 Li H, Huang G, Meng Q, et al. Integrated soil and plant phosphorus management for crop and environment in China. Plant Soil, 2011, 349: $157-167$

14 Cordell D, Drangert J O, White S. The story of phosphorus: global food security and food for thought. Glob Environ Change, 2009, 19:
292-305

15 Stukenholtz D D, Olsen R J, Gogan G, et al. On the mechanism of phosphorus-zinc interaction in corn nutrition. Soil Sci Soc Am Proc, 1966, 30: 759-763

16 Ryan M H, McInerney J K, Record I R, et al. Zinc bioavailability in wheat grain in relation to phosphorus fertiliser, crop sequence and mycorrhizal fungi. J Sci Food Agric, 2008, 88: 1208-1216

17 Fan M S, Zhao F J, Fairweather-Tait S J, et al. Evidence of decreasing mineral density in wheat grain over the last 160 years. J Trace Elem Med Bio, 2008, 22: 315-324

18 Pleijel H, Danielsson H. Yield dilution of grain $\mathrm{Zn}$ in wheat grown in open-top chamber experiments with elevated $\mathrm{CO}_{2}$ and $\mathrm{O}_{3}$ exposure. $\mathrm{J}$ Cereal Sci, 2009, 50: 278-282

19 Kutman U, Yildiz B, Cakmak I. Effect of nitrogen on uptake, remobilization and partitioning of zinc and iron throughout the development of durum wheat. Plant Soil, 2011, 342: 149-164

20 Cakmak I, Kalayci M, Kaya Y, et al. Biofortification and localization of zinc in wheat grain. J Agric Food Chem, 2010, 58: 9092-9102

21 Peterson C J, Johnson V A, Mattern P J. Evaluation of variation in mineral element concentrations in wheat-flour and bran of different cultivars. Cereal Chem, 1983, 60: 450-455

22 Calderini D F, Ortiz-Monasterio I. Grain position affects grain macronutrient and micronutrient concentrations in wheat. Crop Sci, 2003, 43: 141-151

23 Shi R L, Weber G, Koster J, et al. Senescence-induced iron mobilization in source leaves of barley (Hordeum vulgare) plants. New Phytol, 2012, 195: 372-383

24 Uauy C, Distelfeld A, Fahima T, et al. A NAC gene regulating senescence improves grain protein, zinc, and iron content in wheat. Science, 2006, 314: 1298-1300

25 Oikeh S O, Menkir A, Maziya-Dixon B, et al. Genotypic differences in concentration and bioavailability of kernel-iron in tropical maize varieties grown under field conditions. J Plant Nutr, 2003, 26: 2307-2319

26 Oikeh S O, Menkir A, Maziya-Dixon B, et al. Environmental stability of iron and zinc concentrations in grain of elite early-maturing tropical maize genotypes grown under field conditions. J Agric Sci, 2004, 142: 543-551

27 He P, Jin J, Lin B. Effect of nitrogen application rates on leaf senescence and its mechanism in spring maize (Zea mays L.) (in Chinese). Sci Agric Sin, 1998, 31: 66-71

28 Li L, Sun J H, Zhang F S. Intercropping with wheat leads to greater root weight density and larger below-ground space of irrigated maize at late growth stages. Soil Sci Plant Nutr, 2011, 57: 61-67

Open Access This article is distributed under the terms of the Creative Commons Attribution License which permits any use, distribution, and reproduction in any medium, provided the original author(s) and source are credited. 